\title{
IMPACTS OF DIFFERENT MULCHING MATERIAL ON SEEDLING EMERGENCE AND GROWTH PERFORMANCE OF HOT PEPPER (CAPSICUM ANNUM L) AT GURAGE ZONE, ETHIOPIA
}

\author{
KIFLE ZERGA*, MANDEFRO ALEMU, FANTA TEBASA, BIRHANE TESFAYE
}

Department of Horticulture, Wolkite University, Wolkite, Ethiopia

\begin{abstract}
This study was conducted in Gurage Zone at Wolkite University in 2016/17 cropping season. The field experiment was carried out in randomized complete block design (RCBD) using three replications and four treatments. The effect of different mulching material such as grass, banana, plastic and control mulch on growth parameters (plant height, germination rate, leaf number of branch per plant,) of hot pepper was conducted for three months. Data was collected and compared by using LSD at significant level of 0.05. The result showed that the highest and lowest plant height was obtained for grass mulch (T1) and control (T4) on the other hand no plant height was registered for plastic mulch. Generally, from the result of this study we recommended that farmers use of grass mulch increase the rate of hot pepper seedling and growth performance by maintain soil temperature, soil moisture and provide good air circulation with in soil spores than other mulching materials. The awareness of farmers should be increased by providing adequate training regarding with the type of appropriate mulching material, So, they can produce proper operation during the growth of paper to avoid the infestation of weed by mulching. According to analysis of variance there was significant different among treatments on the number of braches per plant and also results of the analysis of variance indicated that different mulching material were shown significantly ( $p>0.05)$ effect on plant height of pepper. However, there is no significant variation among the treatment for number of leaves. Since the recommended using vativar grass mulch until another investigation was done. This is a short term strategy; therefore, the study should be repeated over year. In order to address the significance of all the studied characters and to recommend the appropriate mulching material for further hot pepper production.
\end{abstract}

Keywords: Hot Pepper, Mulching Materials, Vativar Grass

\section{INTRODUCTION}

Hot pepper (Capsicum annuum L.) is a new world crop that belongs to the Solanaceae family, and the genus Capsicum. It is closely related to tomato, eggplant, potato and tobacco. The genus Capsicum is the second most important vegetable crop of the family after tomato in the world $[15,2]$. It is widely cultivated in almost all regions $[6,3]$. The fruit is an excellent source of natural colours and antioxidant compounds whose intake is an important health protecting factor by prevention of widespread human diseases [7]. Pepper fruit contain antioxidants and vitamins which increase its daily consumption worldwide [14].

Hot pepper is a national spice of Ethiopia and believed to be introduced to Ethiopia probably by the Portuguese in the 17 century [5]. Hot pepper has been cultivated in many parts of the country because the powdered hot pepper is a major part of spice used to prepare the traditional sauce called ' $w o t$ ' [12]. The dense plants compete for growth factors such as nutrients, moisture, and light whose effects can be minimized by mulching and adjusting plant population density per unit area Maintaining optimum population density of plants also optimizes yield and quality of crops [11].

The plant yield is mainly proportional to the available moisture in soil and density of plants $[4,18]$. But, farmers of the study area have no enough knowledge and awareness of soil and water conservation practices using mulches and determining appropriate plant population density required per a given area. In addition, there is no study conducted to alleviate the problems of moisture stress using mulching and determined optimum plant spacing to cultivate pepper crop under the agro-climatic conditions of Gurage Zone. Therefore, this research was aimed at attaining the following objective:

To evaluate the seedling emergence and growth response of hot pepper in response to different mulching materials.

\footnotetext{
Received o5 November 2017; Accepted 29 December 2017

*Corresponding Author

Kifle Zerga

Department of Horticulture, Wolkite University, Wolkite, Ethiopia

Email: kiflezerga@gmail.com
}

(CThis article is open access and licensed under the terms of the Creative Commons Attribution License (http://creativecommons.org/licenses/by/4.o/) which permits unrestricted, use, distribution and reproduction in any medium, or format for any purpose, even commercially provided the work is properly cited. Attribution - You must give appropriate credit, provide a link to the license, and indicate if changes were made. 


\section{MATERIALS AND METHODS}

\section{Description of the experimental site}

The experiment was conducted under field condition at Wolkite University, College of Agriculture and Natural Resource, Department of Horticulture during the year $2009 \mathrm{E}$. C in the off season irrigation. Wolkite University is $158 \mathrm{Km}$ geographically located from Addis Ababa, to south west direction. It is also located at about $7.8^{\circ} \mathrm{C} 8.5^{\circ} \mathrm{N}$ latitude and $37.5^{\circ} \mathrm{C} 38.7^{\circ} \mathrm{C}$ longitude. The altitude is about 1300 masl. The mean annual temperature ranges from 14 to $24^{\circ} \mathrm{C}$ with an average of $20.5^{\circ} \mathrm{C}$.

\section{Experimental treatment and design}

The field experimented was carried out in random complete design (RCBD) with three replications and four treatments. The experiment was consisting of three different type of mulches with control which was combine resulting 12 plots combination. The plots were an area of $1.08 \mathrm{~m}^{2}$ (0.9m width and $1.2 \mathrm{~m}$ length) and rows per plot. The spacing between rows is $15 \mathrm{~cm}$ and between plants is $10 \mathrm{~cm}$ was used. The spacing between block iso.5m and spacing between plots is also $0.5 \mathrm{~m}$. The total area that requires $28.56 \mathrm{~m}^{2}$ the method of sowing used will in row. The number of seeds used for planting will 2-3 in one hole to avoid the occurrence of die back after emergence due to as well some incidence of disease and pest attack. The management action was land preparation and leveling applying of water to soften the soil and watering two times a day. Similarly, management activity carried out for all plots except mulches. Data was taken starting from first week of hot pepper emergency. Five plants were randomly selected and tagged from each plot for data management from these plants data was collect such a number of seedling emergency, plant height $(\mathrm{cm})$, total leaf numbers and total number branches.

\section{Method of data collection}

The data of growth parameter was collected randomly by tagged five plants from the center of the plot, with the exception at the border and data of germination percentage by counting the number of germinate seedling immediately after removed mulching materials.

\section{Germination percentage of seed}

Germination percentage was obtained by counting number of seedling and dividing to the total number of seeds that we are sowing.

Germination $(\%)=($ number of seedling $\times 100) /$ total number of seed

\section{Plant height}

The plant height was randomly selected and measured from the ground level to the tip of the main stem.

\section{Number of leaf per plant}

The average number of leaves were counted and recorded at the time of two months after planting

\section{Number of branch}

The average number of branches emerging from the main stem was counted and recorded at the time of harvesting.

\section{Statically analysis}

All data was subjected to analysis of variance by statistical procedures as described by Gomez and Gomez [19]. The mean value of the above described parameter was computed and analysis of variance (ANOVA) was performed using scientific calculator, mean separation was done using least significant difference (LSD) test at $5 \%$ probability level.

\section{Experimental Procedure and Management Practice}

The field of the experiment was selected and prepared; the surface was softening with water. After week seed of hot pepper, 25 seed per plot total of 300 seeds per twelve plots were sown and mulched with 3 three different mulching materials. The plot was receiving $50 \mathrm{~kg} \mathrm{~N}$ and $50 \mathrm{~kg}$ p2 $\mathrm{O}_{5}$ per hectare with urea and Di-ammonium Phosphate (DAP) as the source.

Both of DAP and urea was applied at the planting time while applied two times, means half of at sowing will takes place in mid-march with the depth of $0.4 \mathrm{~cm}$ watering was started from sowing date with the frequency of twice per day to obtain required emergence growth and development. Other cultural practices were carried out per recommendation of areas.

\section{RESULTS AND DISCUSSION}

\section{Day of 50\% Germination}

The analysis of variance showed that different mulching materials had significant influence on the number of days required for hot pepper seed germination at 50\% after planting (sowing) days. The mean performance shows that among different mulching materials used the grass mulch hastens the germination of the seed (11) followed by banana leaves, (13) and controlling ranking order (15). However, no seed germination was recorded for plastic mulch which may be due to high temperature, suffocation, which may damage the seed embryo. Among the mulching materials used the grass mulch shortens the germination period. This result is consistent with that of previous study [17], who reported that early blooming can be attained by the application of polyethylene mulch in case of squash. Similarly, another study [8] found that time to anthesis of watermelon was hastened ( 45 and $55 \mathrm{~d}$ for plastic mulch and control, respectively) by application of plastic mulch compared to the control treatment.

Table 1: The mean performance of different studied characters

\begin{tabular}{|c|c|c|c|c|}
\hline Treatment & Day of $50 \%$ emergence & PH (cm) & LN(No) & BN (No) \\
\hline Grass & {$[11]$} & {$[16] \cdot 2 a$} & {$[14] \cdot 5 \mathrm{a}$} & $7.2 \mathrm{~b}$ \\
\hline Banana & [13] & {$[15]^{\cdot 2 b}$} & $10.4^{\mathrm{a}}$ & $4^{b}$ \\
\hline Plastic & $15 \cdot 3$ & [12] & [11] & 4 \\
\hline Control & {$[15]$} & $12.1^{\mathrm{b}}$ & $8.7 a$ & $3.2^{\mathrm{b}}$ \\
\hline CV (\%) & 21.08 & 8.78 & 10 & 25.06 \\
\hline LSD at $5 \%$ & 4.99 & 1.915 & 11.9 & 1.81 \\
\hline
\end{tabular}




\section{Growth parameters \\ Plant height}

Results of the analysis of variance indicated that different mulching material were shown significantly $(p>0.05)$ effect on plant height of pepper. Moreover, the mean performances numerically the study was able to show there is a difference among the treatments in such a way that the maximum plant height (16.2) was shown from the treatment one followed by treatment two (15.2), treatment four (12.1).

The tallest height was obtained for the plot that is covered with grass mulches followed by banana mulches whereas, the shortest plant height was observed. Whereas, the shortest plant height observed for the control mulch (Appendix table-2). This study indicated that grass mulch is highly significant and significant different was also shown by banana leaves for plant height of hot pepper. But no significance difference was there between plastic mulch and control. So difference in mulching material made of organic (grass, banana leave) resulted in tallest hot pepper growth while inorganic (plastic) caused unfavorable soil condition for hot pepper seed germination.

These findings are in accord with previous study [1], in which it was reported that the transparent polyethylene mulch can increase the height. The okra plant showed increase in height in plastic mulch [13]. The plant height and growth parameters are increasing due to the moisture retention [16].

\section{Number of leaves per plant}

Analysis of variance showed that there was no significant difference among treatments on the number of leaf. Highest number of leaf was observed for grass treatment (T1) followed banana (T2) and the least number of leaves was recorded for control treatment ( $\left.\mathrm{T}_{4}\right)$. This variation may be due to the fact that, grass mulch and banana leaves favors the formation of new leaves and development by maintaining available soil moisture and soil temperature for growth hot pepper compared to the control (Appendix table-3). The effectiveness of plastic mulches for the production of leaves in maize was better than control as reported by [10].

\section{Number of branch per plant}

According to analysis of variance there was significant different among treatments on the number of braches per plant. The greatest number of branch per plant was observed under grass mulch treatment (T1) followed by banana (T2) while the lower number of branch was observed for control treatment ( $\left.\mathrm{T}_{4}\right)$. The present finding is also in agreement with previous findings, that the branch number is directly proportional to the spacing. the investigation of $[9,1]$ in sweet pepper.

Table 1: Analysis of Variance day of $50 \%$ germination

\begin{tabular}{|c|c|c|c|c|c|}
\hline $\begin{array}{l}\text { Source of } \\
\text { variation }\end{array}$ & $\begin{array}{l}\text { Degree of } \\
\text { freedom(df) }\end{array}$ & $\begin{array}{l}\text { Sum of } \\
\text { square(ss) }\end{array}$ & $\begin{array}{l}\text { Mean of } \\
\text { square(ms) }\end{array}$ & Fcal & Ftabulated \\
\hline Replication & 2 & 48.17 & 24.085 & & \\
\hline Treatment & 3 & 2448.92 & 816.30 & $129.57^{*}$ & a4.76 \\
\hline Error & 6 & 37.83 & 6.30 & & \\
\hline Total & 11 & 2534.92 & & & \\
\hline
\end{tabular}

Table 2: Analysis of variance plant height (cm)

\begin{tabular}{|c|c|c|c|c|c|}
\hline $\begin{array}{l}\text { Source of } \\
\text { variation }\end{array}$ & $\begin{array}{l}\text { Degree of } \\
\text { freedom }(\mathrm{df})\end{array}$ & $\begin{array}{l}\text { Sum of square } \\
\text { (ss) }\end{array}$ & $\begin{array}{l}\text { Mean square } \\
\text { (MS) }\end{array}$ & Fcal & Ftabulated \\
\hline Replication & 2 & 4.55 & 2.275 & & \\
\hline Treatment & 3 & 511.37 & 170.45 & $185.27^{*}$ & 4.76 \\
\hline Error & 6 & $5 \cdot 53$ & 0.92 & & \\
\hline Total & 11 & 521.45 & & & \\
\hline
\end{tabular}

Table 3: Analysis of variance leave number

\begin{tabular}{|c|c|c|c|c|c|}
\hline $\begin{array}{l}\text { Source of } \\
\text { variation }\end{array}$ & Degree of freedom (df) & $\begin{array}{l}\text { Sum of } \\
\text { square(SS) }\end{array}$ & Mean of square (ms) & Fcal & Ftabulate \\
\hline Replication & 2 & 4.69 & 2.34 & & \\
\hline Treatment & 3 & 336.93 & 112.31 & $3.06^{\mathrm{Ns}}$ & 4.76 \\
\hline Error & 6 & 219.57 & 36.6 & & \\
\hline total & 11 & 561.19 & & & \\
\hline
\end{tabular}

Table 4: Analysis of variance branch number

\begin{tabular}{|c|c|c|c|c|c|}
\hline Source of variation & Degree of freedom(df) & Sum of square (ss) & Mean square(ms) & Fcal & Ftabulated \\
\hline Replication & 2 & 0.04 & 0.02 & & \\
\hline Treatment & 3 & 80.3 & 26.7 & $32.16^{*}$ & 4.76 \\
\hline Error & 6 & 5.02 & 0.83 & & \\
\hline total & 11 & 85.36 & & & \\
\hline
\end{tabular}




\section{CONCLUSION}

According to analysis of variance there was significant different among treatments on the number of braches per plant and also results of the analysis of variance indicated that different mulching material were shown significantly ( $\mathrm{p}>0.05)$ effect on plant height of pepper. However, there is no significant variation among the treatment for number of leaves.

Generally, from the result of this study we recommended that farmers use of grass mulch increase the rate of hot pepper seedling and growth performance by maintain soil temperature, soil moisture and provide good air circulation with in soil spores than other mulching materials. The awareness of farmers should be increased by providing adequate training regarding with the type of appropriate mulching material, so, they can produce proper operation during the growth of paper to avoid the infestation of weed by mulching.

Since the recommended using vativar grass mulch until another investigation was done. This is a short term strategy; therefore, the study should be repeated over year. In order to address the significance of all the studied characters and to recommend the appropriate mulching material for further hot pepper production.

\section{ACKNOWLEDGEMENT}

Authors would like to thank Wolkite University for financial support, for giving the opportunity to use research field, allocating the required labor, materials for field work and vehicle for the research field supervision.

\section{REFERENCES}

1. Ahmad, I., Hussain, Z., Raza, S., Memon, N., and Naqvi, S. A. 2011. Response of Vegetative and Reproductive Components of Chilli to Inorganic and Organic Mulches. Pakistan Journal of Agricultural Sciences, 48: 19-24.

2. Berhanu Yadeta, DerbewBelew, Wosene Gebresillassie, and Fekadu Marame. 2011. Variability, heritability and genetic advance in hot pepper (Capsicum annuum L.) genotypes in west Shoa, Ethiopia. American-Eurasian Journal of Agriculture and Environmental Science, 10, 587-592.

3. De Witt, D. and Gerlach, N. 1990. The whole Chilli pepper book. Little Brown, and Co., Boston.

4. Friake, N. N., Bangal, G. B., Kenghe R. N., and More, G. M. 1990. Plastic tunnel and mulches forwater conservation. Agricultural Engineering Today, 14(34): 35-39.

5. Hafnagel, H. P. 1961. Agriculture in Ethiopia. Food and Agricultural Organization of United Nations, Rome, Italy.
6. Heiser, C. B. 1976. Peppers Capsicum (Solanaceae). In: N. W. Simmonds (eds). The evolution of crop plants. Longman Press, London, 265-268p.

7. Howard, L. R., Talcott, S. T., Brenes, C. H., and Villalon, B. 2000. Changes in phytochemical and antioxidant activity of selected pepper cultivars (Capsicum sp.) as influenced by maturity. Journal of Agriculture and Food Chemistry, 48:1713-1720.

8. Ibarra-Jimenez, L., Muguia-Lopez, J., Lozano-del, A. J., and Zermeno-Gonzalez, A. 2005. Effect of plastic mulch and row covers on photosynthesis and yield of watermelon. Australian Journal of Experimental Agriculture, 44: 91-94.

9. Islam, M., Saha, S., Akand, MD. H., and Abdur, M. D. 2011. Effect of spacing on growth and yield of sweet pepper (Capsicum annuum L.). Journal of Central European Agriculture, 12:328-335.

10. Izakovic, R. (1989), Effect of plastic mulch on the yield and some traits of maize lines. Rostlinna Vyroba. 35 , 973-980.

11. Lorenzo, P., and Castilla, N. 1995. Bell pepper yield response to plant density and radiation inunheated plastic greenhouse. Acta Horticulturae, 412:330-334.

12. MARC (Melkasa Agricultural Research Center). 2004. Progress Report on Completed Activities. pp: 1-7.

13. Olabode, O. S., Ogunyemi, S., and Adesina, G. O. 2007. Response of okra [Abelmoschus esculentum (L.) Moensh] to weed control by mulching. Journal of Food, Agriculture and Environment, 5:324-326.

14. Robi, R., and Sreelathakumary, I. 2004. Influence of maturity at harvest on capsaicin and ascorbic acid content in hot chilli (Capsicum chinense Jacq.). Capsicum and Eggplant Newsletter, :13-16.

15. Rubatzky, V. E, and Yamaguchi, M. M. 1997. World vegetables: principles, production and nutritive values, 2nd ed., Chapman and Hall International Thomson Publishing, New York, 843p.

16. Tindall, J. A., Beverly, R. B., and Radcliffe, D. E. 1990. Mulch effect on soil properties and tomato growth using micro-irrigation. Agronomy Journal, 83:10281034 .

17. Tuli, A., and Yesilsoy, M. S. 1997. Effect of soil temperature on growth and yield of squash under different mulch applications in plastic tunnel and openair. Turkish Journal of Agriculture and Forestry, 21:101-8.

18. Yahaya, R. A., Aliyu, L., and Mahmud, M. 2010. Effects of Sheep Manure and Intra Row Spacing on yield and yield components of chilli pepper (Capsicum frutescence L.) at, Nigeria. Department of Agronomy, Ahmadu Bello University Zaria, 6: 45-50.

19. Gomez, K.A., Gomez, A.A. 1984. Statistical procedure for agricultural research. $2^{\text {nd }}$ Edition. IRRI, Los Banos. pp. 680 . 